\title{
OPTIMIZATION OF FERMENTATION CONDITIONS FOR CELLULASE PRODUCTION BY BACILLUS SUBTILIS CY5 AND BACILLUS CIRCULANS TP3 ISOLATED FROM FISH GUT
}

\author{
Arun K. RAY ${ }^{1^{*}}$, Abhinanda BAIRAGI ${ }^{1}$, Keka SARKAR GHOSH ${ }^{1}$, and Sukanta K. SEN ${ }^{2}$ \\ ${ }^{1}$ Fisheries Laboratory, Department of Zoology, ${ }^{2}$ Microbiology Laboratory, Department of Botany, \\ Visva-Bharati University, Santiniketan, West Bengal, India
}

Ray A.K., Bairagi A., Sarkar Ghosh K., Sen S.K. 2007. Optimization of fermentation conditions for cellulase production by Bacillus subtilis CY5 and Bacillus circulans TP3 isolated from fish gut. Acta Ichthyol. Piscat. 37 (1): 47-53.

Background. Microbial and fungal cellulases are known to hydrolyse cellulose, which is ingested as plant material by herbivorous/omnivorous fishes. Microbial enzymes have enormous advantage of being produced in large quantities by established fermentation techniques. The present investigation aims to optimize the environmental and nutritional parameters for fermentation to enhance cellulase production by two bacterial strains isolated from fish gastrointestinal tracts.

Materials and methods. Two bacterial strains, Bacillus subtilis CY5 and Bacillus circulans TP3, isolated from the gastrointestinal tracts of common carp, Cyprinus carpio L., and Mozambique tilapia, Oreochromis mossambicus (Peters, 1852), respectively were identified as potent cellulase producers. Both strains were cultured in tryptone soya broth for $24 \mathrm{~h}$ at $32 \pm 2^{\circ} \mathrm{C}$, when average viable count of $9.75 \cdot 10^{7}$ cells $\cdot \mathrm{mL}^{-1}$ culture broth was obtained. This was used as the inoculum for the production medium. The fermentation medium was seeded with $1.0 \%, 2.0 \%, 3.0 \%, 4.0 \%$, and $5.0 \%$ inoculum (tryptone soya broth) and incubated in static culture at $40^{\circ} \mathrm{C}$ to standardize the inoculum size for fermentation. The effect of different production parameters, such as fermentation condition, moisture, $\mathrm{pH}$, temperature, inoculum size, and nitrogen sources on cellulase production by the isolated bacterial strains were studied.

Results. Cellulase yield was highest (26 U in B. subtilis and $20.2 \mathrm{U}$ in B. circulans) in solid-state fermentation (SSF). Enzyme production in both the isolates increased in an optimum $\mathrm{pH}$ range of 7.0 to 7.5. Minimum cellulase production was observed at $45^{\circ} \mathrm{C}$, while maximum production was obtained at $40^{\circ} \mathrm{C}$. To standardize the fermentation period for cellulase production, production rate was measured at 12-h intervals up to $120 \mathrm{~h}$. Enzyme production increased for $96 \mathrm{~h}$ of fermentation in both strains, and decreased thereafter. The enzyme production increased with increased inoculum size up to 3.0 percentage points. Asparagine as the nitrogen source was most effective in B. subtilis CY5, while beef extract proved useful in optimizing enzyme production by $B$. circulans TP3.

Conclusion. The results of this study will help to standardize the requirements for optimum production of cellulase by cellulase-producing fish gut bacteria and might contribute towards better fish feed formulation incorporating plant ingredients, especially in the larval stages when the enzyme system is not efficient.

Keywords: fermentation, cellulase production, optimization, fish gut bacteria

\section{INTRODUCTION}

Complete cellulose hydrolysis to glucose demands the action of exoglucanases (also called cellobiohydrolyses), endoglucanases and $\beta$-glucosidases. Exoglucanases (1,4- $\beta$-D-glucan cellobio-hydrolase, EC 3.2.1.91) are usually active on crystalline cellulose and are lacking from incomplete cellulase systems. Endogluconases (1,4- $\beta$-D-glucan-4-glucanohydrolase, EC 3.2.1.4) are more active against the amorphous regions of cellulose and they can also hydrolyse substituted celluloses, such as car- boxymethylcellulose (CMC) and hydroxyethyl-cellulose (HEC). Cellobiohydrolases cleave disaccharide (cellobiose) units either from non-reducing or reducing ends, whereas endoglucanases hydrolyse the cellulose chain internally. $\beta$-glucosidases (EC 3.2.1.21) are needed to cleave cellobiose and other soluble oligosaccharides to glucose (Béguin 1990). Cellulase is used extensively in plant protoplast isolation, plant virus studies, metabolic investigations and genetic modification experiments. Apart from these applications, cellulases are increasingly being used as

\footnotetext{
* Correspondence: Prof. Arun Kumar Ray, Fisheries Laboratory, Department of Zoology, Visva-Bharati University, Santiniketan-731 235, West Bengal, India, phone/fax: +913463 261268, e-mail: arun_rayl@rediffmail.com
} 
additives in pig and cattle feeds (Dovorak 2000, Siciliano-Jones 2001).

Cellulases are easily obtained from microbial and fungal sources, but vertebrates lack the ability to produce endogenous cellulases, and hence are reliant upon gastrointestinal microorganisms for cell wall degradation of ingested plants. The beneficial effects of microorganisms in the digestive processes of terrestrial animals are well established (Combe et al. 1976, McBee 1977, Savage 1977 a, b, Goldin 1986, Moriarty 1990). Some investigations have also suggested that microorganisms have a beneficial effect in fish digestive processes e.g., microbial breakdown of chitin (Minami et al. 1972, Goodrich and Morita 1977, Danulat and Kausch 1984, Kono et al. 1987), p-nitrophenyl- $\beta$-N-acetylgalactosamine and collagen (MacDonald et al.1986), cellulose (Stickney and Shumway 1974, Trust et al. 1979, Saha and Ray 1998, Bairagi et al. 2002 a, b, 2004, Saha et al. 2006), and the vitamin $\mathrm{B}_{12}$ producing ability of the bacteria (Sugita et al. 1991). However, the specific cellulolytic activity shown by the bacterial species is found to depend on the source (Saxena et al. 1993).

Microbial enzymes have the enormous advantage of being able to be produced in large quantities by established fermentation techniques. Enzyme production is closely controlled in microorganisms and therefore, to improve its productivity these controls can be exploited and modified. Cellulase yields appear to depend on a complex relationship involving a variety of factors like inoculum size (carbon source and cellulose quality), $\mathrm{pH}$ value, temperature, presence of inducers, medium additives, aeration, growth time, etc. (Immanuel et al. 2006). Therefore, attention has been focused on studying the cellulolytic activity and cellulase enzyme production by several microorganisms in various products as well as in various environments. To establish a successful fermentation process it is necessary to make the environmental and nutritional conditions favourable for the microorganism for over-production of the desired metabolite. An elaborate investigation is therefore, required to establish the optimum conditions to scale up enzyme production in an individual fermentation process. Although there are reports on the influence of various fermentation variables on cellulase production by different bacteria and fungi isolated from various natural environments (GarciaMartinez et al. 1980, Stewart and Parry 1981, Coral et al. 2002, Rajoka 2004, Immanuel et al. 2006), information on the optimum fermentation conditions for cellulase production by fish gut bacteria is lacking. In the present investigation, the environmental and nutritional parameters for fermentation were optimized to enhance cellulase production by the bacterial strains B. subtilis CY5 and B. circulans TP3, isolated from the gut of common carp, Cyprinus carpio L., and Mozambique tilapia, Oreochromis mossambicus (Peters, 1852), respectively.

\section{MATERIALS AND METHODS}

Microorganisms and growth medium. The two bacterial strains B. subtilis CY5 and B. circulans TP3, isolated from the gastrointestinal tract of common carp, C. carpio and Mozambique tilapia, O. mossambicus, respectively (Bairagi et al. 2002 a), were identified as potent cellulase producers. Both strains were cultured in 4-\% tryptone soya broth for $24 \mathrm{~h}$ at $37 \pm 2^{\circ} \mathrm{C}$ when an average viable count of $9.75 \cdot 10^{7}$ cells $\cdot \mathrm{mL}^{-1}$ culture broth was obtained. This was used as the inoculum for the production medium, as required.

Medium composition. Carboxymethylcellulose-agar (CMC-agar) medium $\left(\mathrm{g} \cdot \mathrm{L}^{-1}\right)$ : Carboxymethylcellulose, $10 ; \mathrm{KH}_{2} \mathrm{PO}_{4}, 4 ; \mathrm{Na}_{2} \mathrm{HPO}_{4}, 4 ; \mathrm{MgSO}_{4} 7 \mathrm{H}_{2} \mathrm{O}, 0.2 ; \mathrm{CaCl}_{2}$, 0.001; $\mathrm{FeSO}_{4} 7 \mathrm{H}_{2} \mathrm{O}, 0.004$; Tryptone, 2; Agar, 15; pH 7.0. Enzyme assay. Liquid media were used for the quantitative assay of cellulase production from the two bacterial strains. Cellulase activity was measured according to the method of Denison and Koehn (1977). The production of reducing sugar (glucose) from CMC substrate through cellulolytic activity was measured at $540 \mathrm{~nm}$ by the dinitrosalicylic acid method using glucose as the standard. One cellulase unit (U) was defined as the amount of enzyme per millilitre culture filtrate that released 1 microgram glucose per minute.

Fermentation conditions. Fermentation was carried out at $\mathrm{pH} 7.0,37 \pm 2^{\circ} \mathrm{C}$, for $72 \mathrm{~h}$, if not stated otherwise.

Optimization of moisture content in fermentation process. To determine the optimum moisture content in the fermentation process, the microorganisms were cultured in carboxymethylcellulose (CMC) medium, which was prepared by moistening CMC with a basal salt solution. The moisture content of the fermentation medium varied from $5 \%-100 \%$.

Optimization of $\mathbf{p H}$ and temperature. The most suitable $\mathrm{pH}$ of the fermentation medium was determined by adjusting the $\mathrm{pH}$ of the culture medium at different levels in the range of $\mathrm{pH} 5.5-8.5$ using buffers. In order to determine the effective temperature for cellulase production by the selected strains, fermentation was carried out at $5^{\circ} \mathrm{C}$ intervals in the range of 25 to $45^{\circ} \mathrm{C}$.

Optimization of period for cellulase fermentation. Fermentation period is an important parameter for enzyme production by microorganisms. In this experiment fermentation was carried out up to $120 \mathrm{~h}$, and production rate measured at 12 -h intervals.

Optimization of inoculum size for fermentation process. The inoculum volume was optimized for maximal enzyme production. The fermentation medium was seeded with $1.0 \%, 2.0 \%, 3.0 \%, 4.0 \%$, and $5.0 \%$ seed culture (tryptone soya broth) and incubated in still culture at $37^{\circ} \mathrm{C}$.

Effect of nitrogen sources on cellulase production. To detect the appropriate nitrogen source for cellulase production by the isolates, the fermentation medium was supplemented with five inorganic (ammonium nitrate, ammonium chloride, ammonium sulphate, potassium nitrate and sodium nitrate) and five organic (arginine, L-asparagine, tryptophane, tyrosine and beef extract) nitrogen compounds at $0.2-\%$ level, replacing the prescribed nitrogen source of the fermentation medium.

Statistical analysis. The data were subjected to analysis of 
variance (ANOVA) using Origin 6.1 software. Duncan's multiple range test (Duncan 1955) was employed to test differences among means. The significance of differences was tested at the significance level $P=0.05$.

\section{RESULTS}

Cellulase yield was highest (26 U in B. subtilis CY5 and 20.2 U in B. circulans TP3) when the moisture content in the fermentation medium was $10 \%$. However, the production of cellulase by $B$. circulans TP3 at $10 \%$ moisture content was not significantly different from that at $15 \%$ and $20 \%$ (Fig. 1). Thus, cellulase yield increased under solid-state fermentation (SSF) conditions rather than under submerged fermentation $(\mathrm{SmF})$, when the moisture content was $100 \%$. Enzyme production in both the isolates increased with $\mathrm{pH}$ up to $\mathrm{pH} 7.5$ although the value was not significantly different $(P<0.05)$ from those with $\mathrm{pH} 7$ and 8 (Fig. 2). Production was much less up to $\mathrm{pH} 6.5$, and declined again beyond $\mathrm{pH}$ 8. The effect of temperature on cellulase production by the bacterial isolates is depicted in Fig. 3. Minimum cellulase yield was observed when fermented at $45^{\circ} \mathrm{C}$, while maximum yield was at $40^{\circ} \mathrm{C}$. Cellulase production gradually increased for up to $96 \mathrm{~h}$ of fermentation in both strains and decreased thereafter (Fig. 4). Enzyme production increased gradually up to $3 \%$ inoculum size, but decreased thereafter. The enzyme production by both the strains in 3\% inoculum size was however, not significantly different $(P<0.05)$ from that in $2 \%$ inoculum size (Fig. 5). The results of the effect of various nitrogen sources on cellulase production revealed that L-asparagine was most effective for $B$. subtilis CY5, while beef extract produced optimum results for B. circulans TP3 (Fig. 6). All the inorganic nitrogen sources and arginine and tyrosine among the organic sources tested were found to be poor nitrogen sources for cellulase production by both the strains.

\section{DISCUSSION}

Regardless of the fermentation process that is used to grow cells, it is necessary to monitor and control parameters starting from the selection of optimum carbon and nitrogen sources and including inoculum volume, moisture content, $\mathrm{pH}$, temperature, incubation period etc. Changes in one of these parameters can have a dramatic effect on the yield of cells and the stability of protein product. The high rate of metabolism supports the critical period of metabolite production. Consequently, adequate and timely supply of carbon and nitrogen can be key factors affecting peak productivity levels and their duration. The meaning of optimization in this context needs careful consideration of the environmental and nutritional parameters for growth and production.

Medium formulation is the foremost step for designing successful laboratory experiments for yield enhancement. The medium constituents must satisfy the elemental requirement for cell biomass and metabolite production; hence there must be adequate energy supply for biosynthesis and cell maintenance. The first step to consider is an equation based on the stoichiometry for growth and product formation. Thus, for an aerobic fermentation the reaction is as follows:

Carbon and energy source + nitrogen source + oxygen + + other requirements $\longrightarrow$

biomass + products $+\mathrm{CO}_{2}+\mathrm{H}_{2} \mathrm{O}+$ heat

This equation should be expressed in quantitative terms for economical designing of the medium to control the unspent nutrients. Thus, it is possible to calculate the minimal nutrient quantities that are needed to produce a sufficient amount of biomass. Substrate selection of a for enzyme production in a solid state fermentation (SSF) process depends upon several factors, mainly related with substrate cost and availability and thus may involve screening several agro-industrial residues. In the course of this study, macrophyte leaf meals such as Lemna polyrhiza and Leucaena leucocephala were considered as substrates for fermentation. In a SSF process, the solid substrate not only supplies nutrients to the microbial culture growing in it but also serves as an anchorage for the cells. The substrate that provides all the required nutrients to the microorganisms growing in it should be considered as the ideal substrate. In the present experiment, CMC sodium salt (high viscosity) was used as the standard carbon source for optimizing cellulase production.

The requirement of water for growth and metabolic activities of microorganisms and the consequent potential of the water activity of the medium in controlling fermentation processes are well established (Hahn-Hägerdal 1986). SSF is distinct from submerged fermentation (SmF) since microbial growth and product formation occur at or near the surface of the solid substrate particle having low moisture contents. Hence, it is crucial to provide optimized water content to the fermenting substrate. It has been reported that $\alpha$-amylase production by B. licheniformis M27 in SSF was highest in basal wheat bran medium with $65 \%(\mathrm{w} / \mathrm{w})$ initial moisture content (Ramesh and Lonsane 1990). In the present study, it was observed that $10 \mathrm{~mL}$ of distilled water was sufficient to moisten $100 \mathrm{~g} \mathrm{CMC}$ to give high enzyme titres. It appears, therefore, that $10 \%$ moisture content of the medium volume was optimum for cellulase production by B. subtilis and B. circulans. Tendargy (1998) compared cellulase production in SmF and SSF systems. While the production cost in SSF in situ was much less than SmF, the enzyme in SSF crude product was concentrated; thus it could be directly used in agro-biotechnological applications as a feed additive. It has been argued that with appropriate technology, improved bioreactor design and operation controls, SSF may become a competitive method for cellulase production (Pandey et al. 1999).

Most microorganisms grow optimally within a wide $\mathrm{pH}$ range. In the present study, maximum cellulase activity was recorded between $\mathrm{pH} 7.0$ and 7.5. Immanuel et al. (2006) reported that the cellulolytic enzyme, endogluconase from Cellulomonas, Bacillus, and Micrococcus spp., isolated from estuarine coir netting effluents hydrolyzes substrate in the $\mathrm{pH}$ range of 4.0 to 9.0 , with 


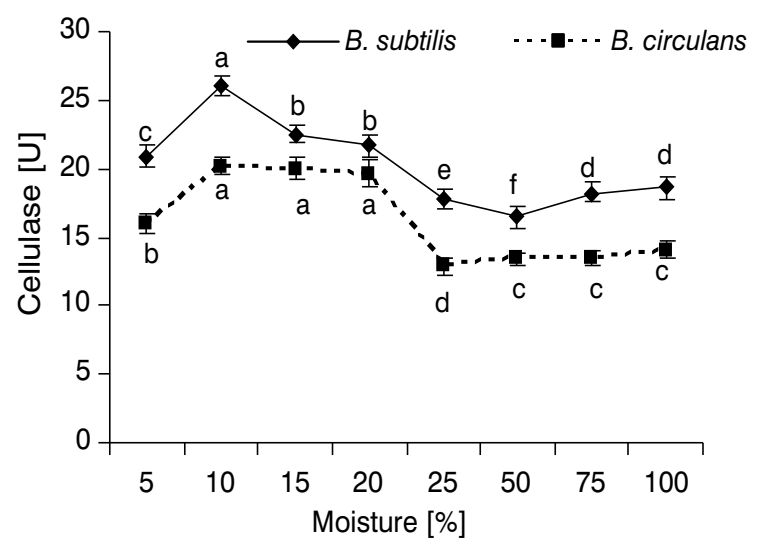

Fig. 1. Effect of moisture on cellulase production by $B$. subtilis CY5 and B. circulans TP3; Error bars show standard deviation among three replicates; Means with different letters are significantly different $(P<0.05)$

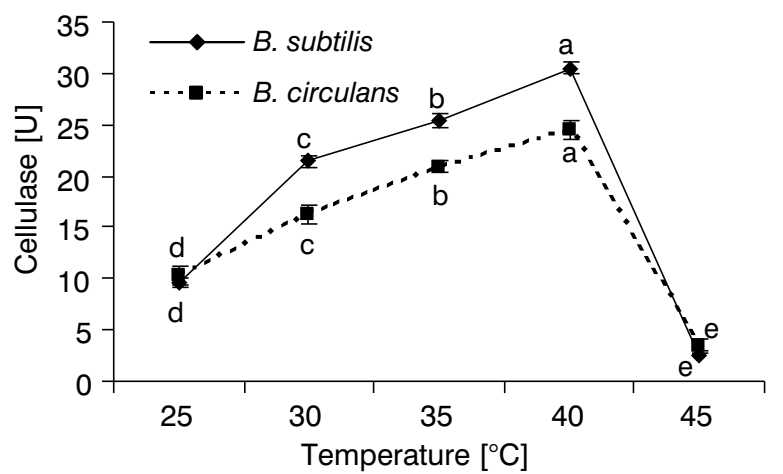

Fig. 3. Effect of temperature on cellulase production by B. subtilis CY5 and B. circulans TP3; Error bars show standard deviation among three replicates;

Means with different letters are significantly different $(P<0.05)$

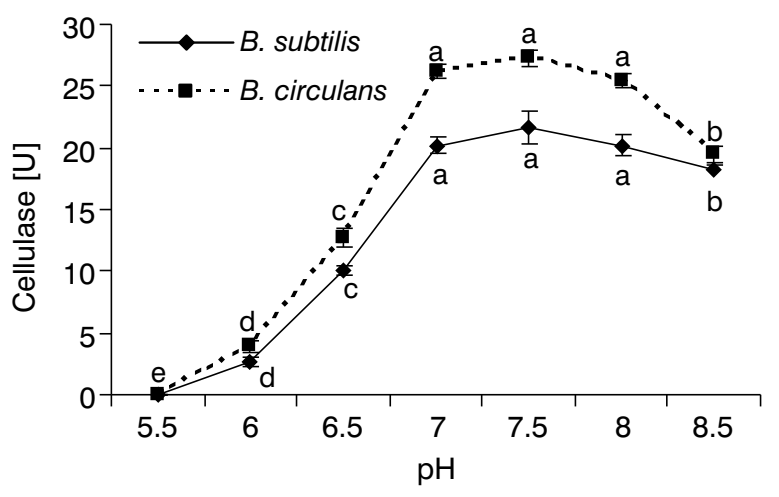

Fig. 2. Effect of pH on cellulase production by B. subtilis CY5 and B. circulans TP3; Error bars show standard deviation among three replicates; Means with different letters are significantly different $(P<0.05)$

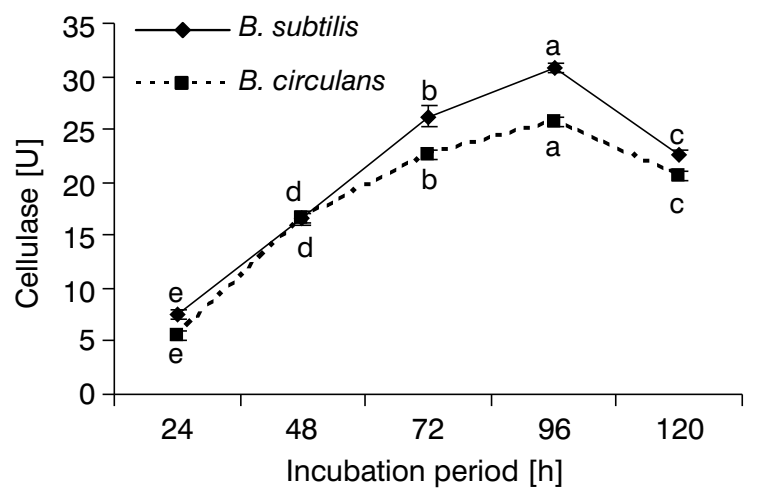

Fig. 4. Effect of incubation period on cellulase production by B. subtilis CY5 and B. circulans TP3; Error bars show standard deviation among three replicates; Means with different letters are significantly different $(P<0.05)$

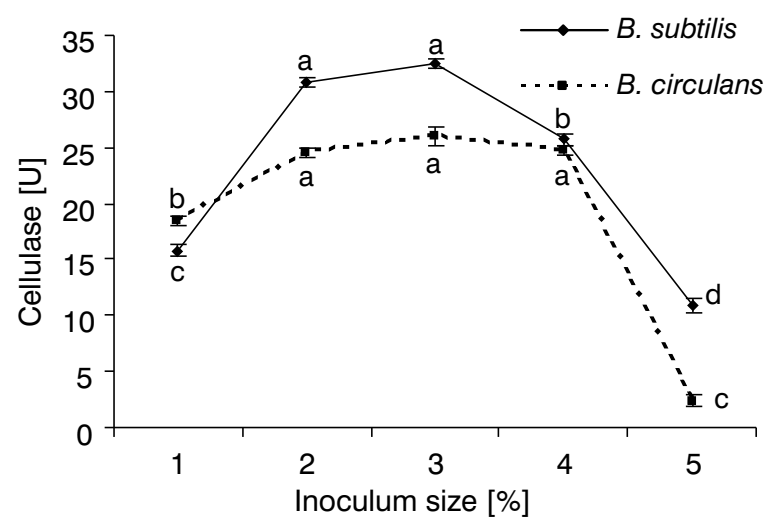

Fig. 5. Effect of percentage of inoculum size on cellulase production by $B$. subtilis CY5 and $B$. circulans TP3; Error bars show standard deviation among three replicates; Means with different letters are significantly different $(P<0.05)$

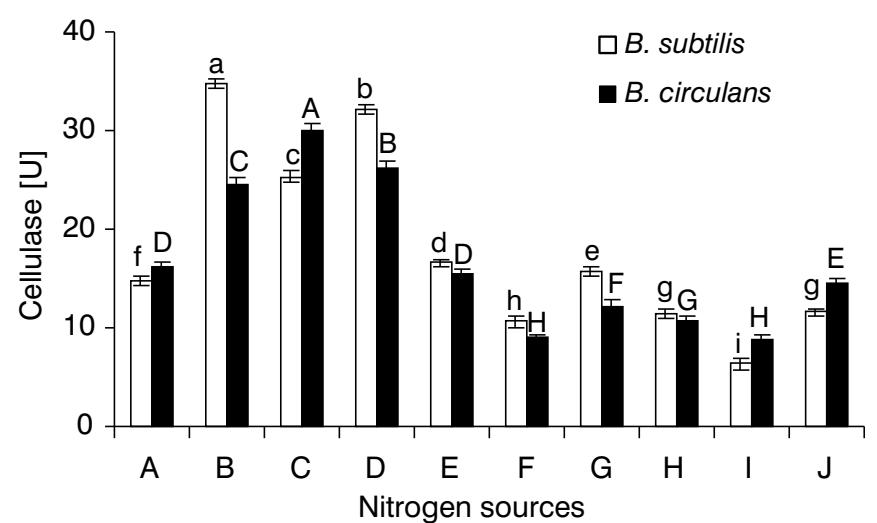

Fig. 6. Effect of different nitrogen sources (A: arginine; B: L-asparagine; C: beef extract; D: tryptophane; E: tyrosine; F: ammonium nitrate; G: ammonium chloride; $\mathrm{H}$ : ammonium sulphate; I: potassium nitrate; $\mathrm{J}$ : sodium nitrate) on cellulase production by $B$. subtilis CY5 and B. circulans TP3; Error bars show standard deviation among three replicates; Means with different letters are significantly different $(P<0.05)$ 
maximum activity at $\mathrm{pH}$ 7.0. The enzyme maintained its stability over a wide $\mathrm{pH}$ range (6.0 to 8.0$)$, but had maximum activity at $\mathrm{pH}$ 7.0. Coral et al. (2002) reported maximum CMCase activity at $\mathrm{pH} 7.5$ by Aspergillus niger (Z10, wild type strain) among the tested $\mathrm{pH}$ range between 4.0 and 9.0. Similarly, the optimal $\mathrm{pH}$ of 6.0 to 7.0 for maximum protease-resistant cellulase activity in $A$. niger was reported by Akiba et al. (1995). Some earlier studies reported that $\mathrm{pH} 7.0$ appears to play a decisive role in cellulose digestion for maximum production by Clostridium thermocellum and Cellulomonas sp. (Garcia-Martinez et al. 1980, Prasetsan and Doelle 1987). Rajoka (2004), however, reported $\mathrm{pH} 7.3$ as optimum for production of $\beta$-cellobiohydrolase $(\mathrm{CBH})$ in Cellulomonas flavigens.

Like $\mathrm{pH}$, temperature is one of the most important parameters essential for the success of a fermentation reaction. Microorganisms grow slowly at a temperature below or above the normal growth temperature because of a reduced rate of cellular production. If the growth temperature is too high but not lethal, there may be a premature induction of target protein expression. For cellulase production by $B$. subtilis $\mathrm{CY} 5$ and $B$. circulans $\mathrm{TP} 3,40^{\circ} \mathrm{C}$ was found to be most effective. Production started to decline after further increase in temperature. Immanuel et al. (2006) also recorded maximum endoglucanase activity in Cellulomonas, Bacillus, and Micrococcus sp. at $40^{\circ} \mathrm{C}$ at neutral $\mathrm{pH}$. Further increase in $\mathrm{pH}$ and temperature reduced the enzyme activity considerably. Coral et al. (2002) reported the optimum temperature for CMCase activity as $40^{\circ} \mathrm{C}$ in Aspergillus niger Z10 strain. Rajoka et al. (1998) and Rajoka (2004), however, observed suppressed exoglucanase production at temperatures higher than $30^{\circ} \mathrm{C}$ in Cellulomonas biazotea and C. flavigens, respectively. At lower temperature, substrate transport across the cells is suppressed and lower product yields are attained. At higher temperature, the maintenance energy requirement for cellular growth is high due to thermal denaturation of enzymes of the metabolic pathway (Aiba et al. 1973) resulting in maximum production.

The culture used to inoculate the fermentation medium must be in a healthy, active state and of optimum size, possibly minimizing the length of log phase, thus in its high rate for substrate conversion. The inoculum quantity of normally used is between $3 \%$ and $10 \%$ of the medium volume (Lincoln 1960, Meyrath and Suchanek 1972, Hunt and Stieber 1986). A relatively large inoculum volume may be used to generate the maximum production in as short a time as possible, thus increasing the vessel productivity. The physiological condition of the inoculum, when it is transferred to the next culture stage, can have a major effect on fermentation performance. The optimum transfer time must be determined so that the inoculation with an ideal culture can be achieved. Lincoln (1960) stressed that bacterial inocula should be transferred in the logarithmic growth phase when the cells are still metabolically active. Inoculum age is particularly important in the sporulating bacteria, because sporulation is induced at the end of the logarithmic phase and the use of an inoculum containing high percentage of spores would result a long $\log$ phase in subsequent fermentation. Keay et al. (1972) reported the use of $5 \%$ inoculum for protease production by Bacillus. For the production of raw starch hydrolysing amylase by Bacillus, 2\% inoculum was recommended (Avendano and Cornejo 1987). To determine the optimum inoculum dose and the time of inoculum transfer in the present experiment, the inoculum was transferred after $24 \mathrm{~h}$ of growth, i.e., in its log phase. It was observed that $3 \%$ inoculum at the age of $24 \mathrm{~h}$ was the best.

Since fermentation duration is crucial, it is also important to find out the optimum period for enzyme production. Some organisms are reported to produce maximally in the log phase of growth, whereas some at their stationary phase. Optimum fermentation period was found to be $48 \mathrm{~h}$ for amylase production by B. subtilis (Takasaki 1985). Sidhu et al. (1997) reported that $48 \mathrm{~h}$ of fermentation was optimum for $\alpha$-amylase production by $B$. stearothermophilus MK 716. In the present investigation, however, maximum cellulase production by $B$. subtilis $\mathrm{CY} 5$ and B. circulans TP3 was obtained at $96 \mathrm{~h}$ fermentation.

Most industrially used microorganisms can utilize inorganic or organic nitrogen sources. Inorganic nitrogen may be supplied as ammonia gas, ammonium salts or nitrates and as amino acids, protein or urea. It was found that the growth was faster with the supply of organic nitrogen, and a few microorganisms also were found to have absolute requirement for amino acids. However, amino acids are more commonly added as complex organic nitrogen sources which are non-homogenous, cheaper and readily available. In the present study, the amino acid L-asparagine at $0.2 \%$ level proved to be the best for $B$. subtilis and the complex nitrogen compound beef extract at the same concentration, for $B$. circulans. Inorganic nitrogen sources, including ammonium nitrate, ammonium chloride, ammonium sulphate, potassium nitrate and organic nitrogen sources namely, the amino acids, arginine and tyrosine were the poor nitrogen sources for CMCase synthesis. On the contrary, Spiridonov and Wilson (1998) found that $\mathrm{NH}_{4}$ compounds are the most favourable nitrogen sources for protein and cellulase synthesis. Rajoka (2004) reported $\mathrm{KNO}_{3}$ and $\mathrm{NH}_{4} \mathrm{NO}_{3}$ as the best nitrogen sources for cellulase synthesis in $C$. flavigena.

The nutritional and physical conditions for growth and metabolite production by an organism depend on its genetic make up. However, the production can be improved by standardizing the culture parameters. After the optimization experiments in this investigation it was observed that the cellulase yield doubled even in its wild state. However, the organisms showed very simple nutrient requirement.

\section{CONCLUSION}

This investigation led us to conclude that moisture, $\mathrm{pH}$, temperature, and nitrogen sources play a most crucial role in cellulase production by fish gut bacteria, Bacillus subtilis CY5 and B. circulans TP3. Solid-state fermentation was suitable for increased cellulase production by 
these organisms. They could readily utilize the substrate at $40^{\circ} \mathrm{C}$ temperature and $\mathrm{pH} 7-7.5$. Organic nitrogen sources were found to be more suitable for optimum cellulase production of than inorganic sources. The amino acid, L-asparagine and beef extract were most suitable for optimization of cellulase production by B. subtilis and $B$. circulans, respectively. Further investigations are required to make use of the full potential of these organisms for cellulase production by employing genetic, biochemical and microbial engineering techniques.

\section{ACKNOWLEDGEMENTS}

We are grateful to the Indian Council of Agricultural Research, New Delhi (Project F. No. 4(11)/98-ASR-I) for financial support.

\section{REFERENCES}

Aiba S., Humphrey A.E., Millis N.F. (eds.) 1973. Biochemical Engineering. 2nd edn. Academic Press, New York.

Akiba S., Kimura Y., Yamamoto K., Kumagap H. 1995. Purification and characterization of protease-resistant cellulase from Aspergillus niger. Journal of Fermentation Bioengineering 79: 125-132.

Avendano M.C., Cornejo I. 1987. Formation of a raw starch hydrolysing alpha-amylase by Clostridium 2021: Effect of carbon sources. Biotechnology Letters 9: 123-124.

Bairagi A., Sarkar Ghosh K., Sen S.K., Ray A.K. 2002a. Enzyme producing bacterial flora isolated from fish digestive tracts. Aquaculture International 10: 109-121.

Bairagi A., Sarkar Ghosh K., Sen S.K., Ray A.K. 2002 b. Duckweed (Lemna polyrhiza) leaf meal as a source of feedstuff in formulated diets for rohu (Labeo rohita Ham.) fingerlings after fermentation with a fish intestinal bacterium. Bioresource Technology 85: 17-24.

Bairagi A., Sarkar Ghosh K., Sen S.K., Ray A.K. 2004. Evaluation of nutritive value of Leucaena leucocephala leaf meal inoculated with fish intestinal bacteria Bacillus subtilis and Bacillus circulans in formulated diets for rohu, Labeo rohita (Hamilton) fingerlings. Aquaculture Research 35: 436-446.

Béguin P. 1990. Molecular biology of cellulose degradation. Annual Review of Microbiology 44: 219-248.

Combe E., Dermarne Y., Gueguen L., Ivorec-Szylit O., Meslin J.H., Sacquet E. 1976. Some aspects of the relationships between gastrointestinal flora and host nutrition. World Review of Nutrition and Dietetics 24: 1-57.

Coral G., Arikan B., Ünaldi M.N., Güvenmez H. 2002. Some properties of crude carboxymethyl cellulase of Aspergillus niger Z10 wild-type strain. Turkish Journal of Biology 26: 209-213.

Danulat E., Kausch H. 1984. Chitinase activity in the digestive tract of the cod, Gadus morhua (L.). Journal of Fish Biology 24: $125-133$.

Denison D.A, Koehn R.D. 1977. Cellulase activity of Poronia oedipus. Mycologia 69: 592-601.

Duncan D.B. 1955. Multiple range and multiple $F$-tests. Biometrics 11: 1-42.

Dvorak R.A. 2000. Efficacy of an enzyme/live yeast culture product with and without monensin/tylosin in high grain diets for yearling steers. Abstract No. 259, p. 82, Proceedings of the American Society of Animal Science, Midwestern Section, March 13-15, 2000, Des Moines, IA, USA.

Garcia-Martinez D.V., Shinmyo A., Madia A., Deman A.L. 1980. Studies on cellulase production by Clostridium thermocellum. European Journal Applied Microbiology and Biotechnology 9: 189-197.

Goldin B.R. 1986. In situ bacterial metabolism and colon mutagens. Annual Review of Microbiology 40: 367-393.

Goodrich T.D., Morita R.Y. 1977. Bacterial chitinase in the stomachs of marine fishes from Yaquina Bay, Oregon, USA. Marine Biology 41: 355-360.

Hahn-Hägerdal B. 1986. Water activity: a possible external regulator in biotechnical processes. Enzyme Microbial Technology 8: 322-327.

Hunt G.R., Stieber R.W. 1986. Inoculum development. Pp. 32-40. In: Demain A.L., Solomon N.A. (eds.) Manual of industrial microbiology and biotechnology. American Society of Microbiology, Washington DC.

Immanuel G., Dhanusha R., Prema P., Palavesam A. 2006. Effect of different growth parameters on endoglucanase enzyme activity by bacteria isolated from coir retting effluents of estuarine environment. International Journal of Environmental Science and Technology 3: 25-34.

Keay L., Moseley M.H., Anderson R.G., O'Connor R.J., Wildi B.S. 1972. Production and isolation of microbial proteases. Biotechnology and Bioengineering Symposium 3: 63-92.

Kono M., Matsui T., Shimizu C. 1987. Chitin-decomposing bacteria in digestive tracts of cultured red sea bream and Japanese eel. Bulletin of the Japanese Society of Scientific Fisheries (Nippon Suisan Gakkaishi) 53: 305-310.

Lincoln R.E. 1960. Control of stock culture preservation and inoculum build-up in bacterial fermentations. Journal of Biochemistry, Microbial Technology and Engineering 2: 481-500.

MacDonald N.L., Stark J.R., Austin B. 1986. Bacterial microflora in the gastro-intestinal tract of Dover sole (Solea solea L.) with emphasis on the possible role of bacteria in the nutrient of the host. FEMS Microbiology Letters 35: 107-111.

McBee R.H. 1977. Fermentation in the hindgut. Pp. 185-222. In: Clarke R.T.J., Bauchop T. (eds.) Microbial ecology of the gut. Academic Press, London.

Meyrath J., Suchanek G. 1972. Inoculation techniques-effects due to quality and quantity of inoculum. Pp. 159-209. In: Norris J.R., Ribbons D.W. (eds.) Methods in microbiology. Vol. 7B. Academic Press, London.

Minami Z., Kajinta M., Hibino S. 1972. Studies on the utilization of petro-yeast as diet of freshwater fish. I. The distribution of chitin-decomposing bacteria in digestive tracts. Bulletin of Japanese Society of Scientific Fisheries 38: 1013-1019.

Moriarty D.J.W. 1990. Interactions of microorganisms and aquatic animals, particularly the nutritional role of the gut flora. Pp. 217-222. In: Lésel R. (ed.) Microbiology in Poikilotherms. Elsevier, Amsterdam.

Pandey A., Selvakumar P., Soccol C.R., Nigam P. 1999. Solid state fermentation for the production of industrial enzymes. Current Science 77: 149-162. 
Prasetsan P., Doelle H.W. 1987. Nutrient optimization for cellulase biosynthesis by a newly isolated Cellulomonas sp. Mircen Journal 3: 33-44.

Rajoka M.I. 2004. Influence of various fermentation variables on exo-glucanase production in Cellulomonas flavigena. Electronic Journal of Biotechnology 7: 259-266.

Rajoka M.I, Bashir A., Hussain M.R.A., Malik K.A. 1998. Mutagenesis of Cellulomonas biazotea for improved production of cellulases. Folia Microbiologica 43: 15-22.

Ramesh M.V., Lonsane B.K. 1990. Critical importance of moisture content of the medium in alpha-amylase production by Bacillus licheniformis M27 in a solid-state fermentation system. Applied Microbiology and Biotechnology 33: 501-505.

Saha A.K., Ray A.K. 1998. Cellulase activity in rohu fingerlings. Aquaculture International 6: 281-291.

Saha S., Roy R.N., Sen S.K., Ray A.K. 2006. Characterization of cellulase-producing bacteria from the digestive tract of tilapia, Oreochromis mossambica (Peters) and grass carp, Ctenopharyngodon idella (Valenciennes). Aquaculture Research 37: 380-388.

Savage D.C. 1977a. Microbial ecology of the gastrointestinal tract. Annual Review of Microbiology 31: 107-133.

Savage D.C. 1977b. Interactions between the host and its microbes. Pp. 277-310. In: Clarke R.T.J., Bauchop T. (eds.) Microbial ecology of the gut. Academic Press, London.

Saxena S., Bahadur J., Varma A. 1993. Cellulose and hemi-cellulose degrading bacteria from termite gut and mound soils of India. International Journal of Microbiology 33: 55-60.

Siciliano-Jones J. 2001. Strategies for coping with poor forage digestibility in dairy rations: response to enzyme supplements. Pp. 87-96. In: Lyons T.P., Jacques K.A. (eds.) Science and technology in the feed industry. Proceeding of Altech's 17th Annual Symposium. Nottingham University Press, Nottingham, UK.
Sidhu G.S., Sharma P., Chakraborty T., Gupta J.K. 1997. Strain improvement for the production of thermostable $\alpha$-amylase. Enzyme and Microbial Technology 21: 525-530.

Spiridonov N.A., Wilson D.B. 1998. Regulation of biosynthesis of individual cellulases in Thermomonospora fusca. Journal of Bacteriology 180: 3529-3532.

Stewart J.C, Parry J.B. 1981. Factors influencing the production of cellulase by Aspergillus fumigatus (Fresenius). Journal of General Microbiology 125: 33-39.

Stickney R.R., Shumway S.E. 1974. Occurrence of cellulase activity in the stomachs of fish. Journal of Fish Biology $\mathbf{6}$ : 779-790.

Sugita H., Miyajima C., Deguchi Y. 1991. The vitamin $\mathrm{B}_{12}$-producing ability of the intestinal microflora of freshwater fish. Aquaculture 92: 267-276.

Takasaki Y. 1985. An amylase producing maltotriose from Bacillus subtilis. Agricultural Biological Chemistry 49: 1091-1097.

Tengerdy R.P. 1998. Solid substrate fermentation for enzyme production. Pp. 13-16. In: Pandey A. (ed.) Advances in biotechnology. Educational Publishers and Distributors, New Delhi.

Trust T.J., Bull L.M., Currie B.R., Buckley J.T. 1979. Obligate anaerobic bacteria in the gastrointestinal microflora of the grass carp (Ctenopharyngodon idella), goldfish (Carassius auratus), and rainbow trout (Salmo gairdneri). Journal of Fisheries Research Board of Canada 36: 1174-1179.

Received: 9 March 2007

Accepted: 3 July 2007

Published electronically: 15 July 2007 